\title{
$\omega$-Conotoxin Sensitivity and Presynaptic Inhibition of Glutamatergic Sensory Neurotransmission in vitro
}

\author{
W. Gruner and L. R. Silva \\ Department of Physiology, Tufts University School of Medicine, Boston, Massachusetts 02111
}

\begin{abstract}
Synaptic transmission between embryonic chick dorsal root ganglion (DRG) neurons and spinal cord neurons was studied in dissociated cell culture. Stimulation of DRG neurons evoked monosynaptic and polysynaptic excitatory responses in the spinal neurons. These responses could be reversibly blocked by application of 6-cyano-7-nitroquinoxaline-2,3-dione (a selective non-NMDA receptor antagonist) and irreversibly eliminated through the presynaptic action of w-conotoxin GVIA (a selective $\mathbf{N}$-type calcium channel antagonist). As $\mathrm{N}$-type calcium channels in DRG neuron somata are targets for modulation via $\mathrm{GABA}_{\mathrm{B}}$ receptors, we tested the role of these receptors as regulators of synaptic transmission. Baclofen (a selective $\mathrm{GABA}_{B}$ receptor agonist) reversibly inhibited synaptic transmission via a presynaptic, pertussis toxin-sensitive mechanism; CGP 35348 (a selective $\mathrm{GABA}_{\mathrm{B}}$ receptor antagonist) blocked the actions of baclofen. Taken together, these results demonstrate that $\mathrm{N}$-type calcium channels play a dominant role in glutamatergic sensory neurotransmission. They suggest, in addition, that modulation of $\mathrm{N}$-channel activity may underlie, at least in part, presynaptic inhibition of synaptic transmission between DRG neurons and their targets in the intact spinal cord.
\end{abstract}

[Key words: calcium channel, dorsal root ganglion, $G_{A B A_{B} \text {, }}$ presynaptic inhibition, primary afferent, synaptic transmission, $\omega$-conotoxin]

Sensory information from the skin, muscles, joints, and viscera is relayed to the CNS by dorsal root ganglion (DRG) neurons, which synapse in the spinal cord. DRG axons contain and releasc a number of putative ncurotransmitters, including peptides such as substance P (Hokfelt et al., 1976; DeBiasi and Rustioni, 1988) and excitatory amino acids (EAAs) (Roberts, 1974; DeBiasi and Rustioni, 1988; Kangrga and Randic, 1991). Physiological data demonstrate that DRG neurons employ glutamate for fast, excitatory neurotransmission (Jahr and Jessell, 1985; Jessell et al., 1986); postsynaptic spinal neuron responses are mediated via both NMDA and non-NMDA type glutamatergic receptors (Yoshimura and Jessell, 1990; Pinco and Lev-Tov, 1991). In

\footnotetext{
Received Apr. 30, 1993; revised Oct. 4, 1993; accepted Oct. 14, 1993.

We especially thank Dr. Kathleen Dunlap, who conceived this project and provided preliminary results, laboratory support, and help with the manuscript. We also thank Drs. T. Jessell and T. J. Tumer for their comments on the manuscript. Dr. Roger Nicoll graciously provided information about CGP 35348 , and Drs. L. Maitre and H. Kaufmann at Ciba-Geigy generously supplied us with a sample. This work was supported by U.S. Public Health Service Grants NS16483 and NS28815 to Dr. Kathleen Dunlap and individual NRSA awards to W.G. (NS08955) and L.R.S. (NS09099).

Correspondence should be addressed to L. R. Silva, Department of Neuroscience, Box G-M, Brown University, Providence, RI 02912.

Copyright (C) 1994 Society for Neuroscience $0270-6474 / 94 / 142800-09 \$ 05.00 / 0$
}

addition, substance $P$ released by DRG axon terminals elicits a low-amplitude, prolonged EPSP in spinal cord neurons (Urban and Randic, 1984; DeKoninck and Henry, 1991; Yoshimura et al., 1992).

Neurotransmission at the DRG-spinal cord synapse is subject to presynaptic regulation by spinal cord interneurons that synapse on DRG axon terminals (Barber et al., 1978). GABAmediated presynaptic inhibition, in particular, appears to play a powerful regulatory role in both sensory and motor function. GABA and GABA receptor agonists have antinociceptive and antispastic effects and depress spinal reflexes (Paredes and Agmo, 1992); these actions have been shown to be mediated, at least in part, via GABA receptors on DRG axon terminals.

At least two classes of GABA receptor can be distinguishcd on the basis of their pharmacological properties: $\mathrm{GABA}_{\mathrm{A}}$ receptors, which are specifically activated by muscimol and blocked by convulsant agents such as bicuculline, and $\mathrm{GABA}_{\mathrm{B}}$ receptors, which are specifically activated by the antispastic drug baclofen and are blocked by CGP 35348 (Olpe et al., 1990). Both GABA $A_{A}$ and $\mathrm{GABA}_{\mathrm{B}}$ receptors appear to mediate presynaptic inhibition at the DRG-spinal neuron synapse. The pioneering studies on presynaptic inhibition by Eccles and colleagues described an activity-dependent depolarization at DRG nerve terminals, termed primary afferent depolarization (PAD), that was mediated by GABA (Eccles et al., 1961, 1963). PAD is hypothesized to inhibit transmitter release by reducing the potential change that occurs during a presynaptic action potential and, consequently, reducing calcium influx into the terminal (Eccles, 1964). PAD is blocked by bicuculline and picrotoxin and is thus likely to be mediated by $\mathrm{GABA}_{\mathrm{A}}$ receptors (Eccles et al., 1963; Curtis et al., 1971; Barker and Nicoll, 1973).

Evidence has accumulated over the past decade that presynaptic inhibition of DRG nerve terminals is also mediated by $\mathrm{GABA}_{B}$ receptors. $\mathrm{GABA}_{B}$ receptors are localized on primary afferent terminals (Price et al., 1984), and baclofen reduces transmitter release by primary afferents (Davies, 1981). Baclofen has been shown to reduce sensory neurotransmission, at least in part via a presynaptic mechanism, in numerous studies in vitro (Davies, 1981; Peng and Frank, 1989; Wang and Dun, 1990; Alford and Grillner, 1991; Kangrga et al., 1991) and in vivo (Dickenson et al., 1985; Lev-Tov et al., 1988; Jimenez et al., 1991). These actions are mechanistically distinct from $\mathrm{GABA}_{\mathrm{A}}$ receptor-mediated presynaptic responses; baclofen's presynaptic inhibitory actions occur in the absence of PAD and, not surprisingly, are unaffected by $\mathrm{GABA}_{\mathrm{A}}$ receptor blockers such as bicuculline.

The mechanisms that do underlie $\mathrm{GABA}_{\mathrm{B}}$ receptor-mediated presynaptic inhibition, however, are still controversial. Dunlap (1981) and Dunlap and Fischbach (1981) demonstrated that 

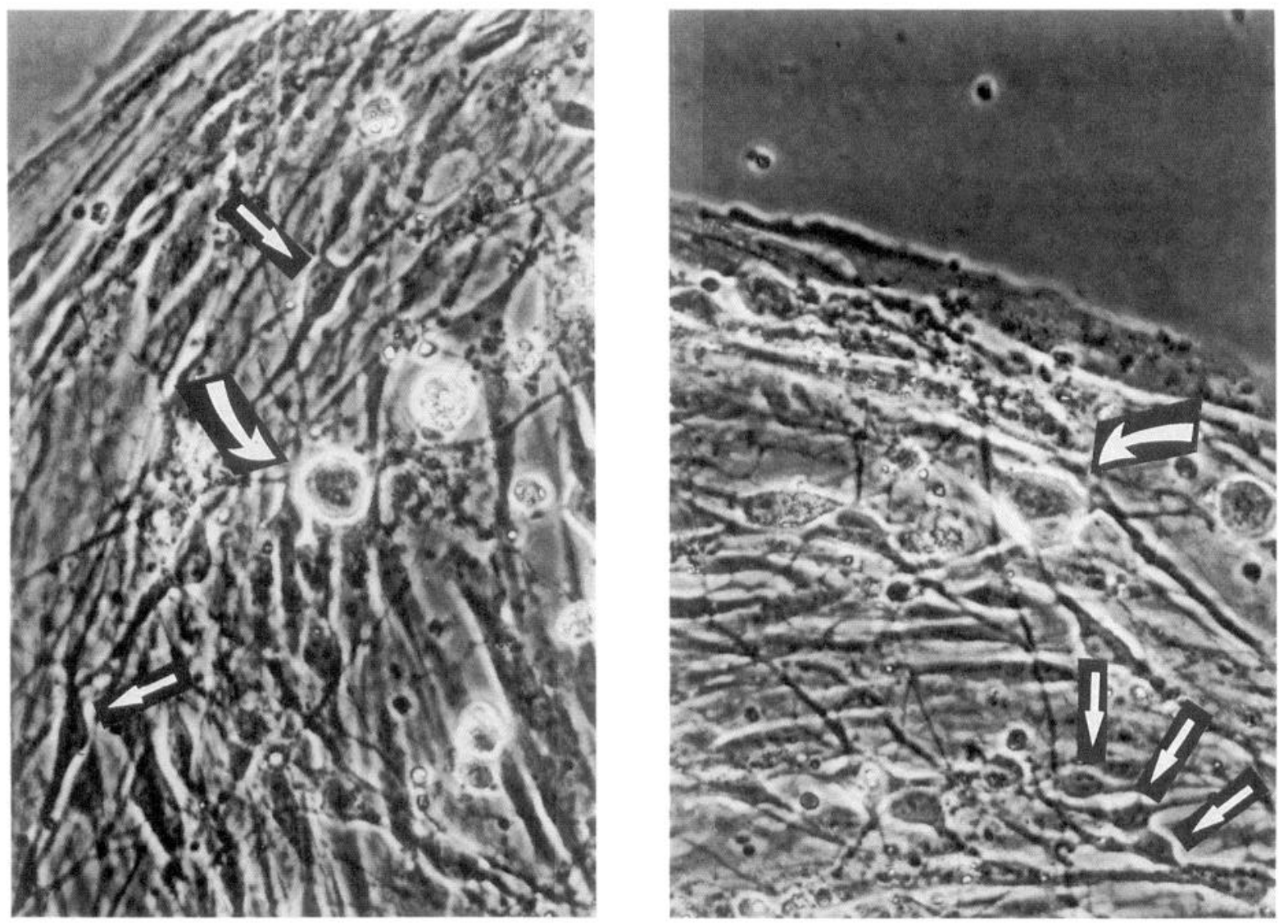

Figure 1. DRG and spinal cord neurons in dissociated cell culture. The phase-contrast photographs show phase-bright DRG neurons (larger arrows) and phase dark spinal neurons (smaller arrows) grown together at low density on collagen islands. Note the different morphologies of the two cell types. Neuronal attachment and process outgrowth were confined to collagen islands; the edge of one island is shown in the right panel. Magnification, $400 \times$

GABA and baclofen inhibit voltage-gated calcium currents in DRG cell bodies. This finding led to the hypothesis (Dunlap, 1981) that GABA causes presynaptic inhibition at DRG axon terminals via a $\mathrm{GABA}_{\mathrm{B}}$ receptor-mediated reduction of calcium current.

To characterize further the $\mathrm{GABA}_{\mathrm{B}}$ receptor-mediated inhibition of primary afferent terminals, we have established a coculture preparation consisting of dissociated embryonic chick DRG and spinal cord neurons. This has enabled us to make patch-clamp recordings from pairs of synaptically connected DRG and spinal cord neurons.

Portions of these data have been presented in abstract form (Gruner et al., 1992).

\section{Materials and Methods}

Cell culture. The frequency of identifying synaptically coupled pairs of DRG and spinal cord cells varied depending upon culture methods employed. Our most successful experiments ( 76 synaptically coupled pairs in 220 pairs tested) were carried out on cells grown in the following way: spinal cords and dorsal root ganglia were dissected from $7 \mathrm{~d}$ chick embryos and separately incubated for $10 \mathrm{~min}$ at room temperature in $0.025 \%$ trypsin in $\mathrm{Ca}^{2+} / \mathrm{Mg}^{2+}$-free saline. The tissues were then separately resuspended in culture medium consisting of Eagle's Minimum Essential Medium (GIBCO) supplemented with $10 \%$ horse serum (GIB$\mathrm{CO}$ ), $5 \%$ chick embryo extract, $50 \mathrm{U} / \mathrm{ml}$ penicillin, $50 \mu \mathrm{g} / \mathrm{ml}$ streptomycin, and nerve growth factor (NGF). A crude preparation of NGF was prepared by homogenizing male mouse salivary glands in distilled water and spinning out the particulate fraction at $20,000 \times g$ for 60 $\min ; 200 \mu \mathrm{l}$ of supernatant, containing the NGF, was added to $100 \mathrm{ml}$ of the culture medium.

All tissue was triturated in this growth medium until mostly dissociated. The DRG cells were irradiated (5000 rads, cesium source) to prevent proliferation of non-neuronal ganglion cells. The spinal cord and DRG cells were then recombined and plated onto prepared culture dishes and grown at $37^{\circ} \mathrm{C}$ in $5 \% \mathrm{CO}_{2}$ for $5-14 \mathrm{~d}$ before recording.

Culture dishes were prepared using a modification of the technique of Segal and Furshpan (1990). Thirty-five millimeter culture dishes were first coated with $0.15 \%$ agarose. After the agarose dried, an annulus of collagen was painted around the perimeter of each dish, and small collagen dots $(0.2-0.3 \mathrm{~mm}$ diameter) were painted on the interior portion using a pulled tuberculin syringe. This procedure was motivated by the experimental constraint that only cell pairs within the microscopic field of view $(\sim 0.5 \mathrm{~mm})$ could be simultaneously recorded. Because these neurons do not stick to agarose, their attachment and process outgrowth were confined to the collagen islands (Fig. 1). By constraining the DRG axons to a single collagen island, we hoped to increase the number of synapses made onto nearby spinal cord neurons and thereby increase the proportion of recordable synaptically coupled pairs. The annulus of collagen provided a mass culture around the perimeter of the dish, which proved necessary for maintaining healthy neurons on the islands.

Solutions. All recordings were made at room temperature $\left(22-26^{\circ} \mathrm{C}\right)$. Cells were visualized at a magnification of $512 \times$, using phase contrast optics on a Zeiss Axiovert microscope. The bath solution contained, in $\mathrm{mm}, \mathrm{NaCl}, 145 ; \mathrm{KCl}, 5$; Na-HEPES, $10 ; \mathrm{MgCl}_{2}, 1 ; \mathrm{CaCl}_{2}$, 3; and glucose, 10. The electrode solution consisted of, in mM, K-Asp, 100; $\mathrm{KCl}, 15$; $\mathrm{Na}_{2} \mathrm{ATP}, 1.5 ; \mathrm{MgCl}_{2}, 1.5$; EGTA, 0.5; and Na-HEPES, 10. Assuming $10 \mu \mathrm{M}$ contaminating $\mathrm{Ca}^{2+}$ and using the equations of Fabiato and Fabiato (1979), this solution would have a free calcium concentration of $2 \mathrm{~nm}$. Extracellular solutions were exchanged via gravity flow and 
vacuum suction at a flow rate of $1-2 \mathrm{ml} / \mathrm{min}$. The bath volume was kept approximately at $1 \mathrm{ml}$. Pertussis toxin (PTX) was stored as a stock solution of $170 \mu \mathrm{g} / \mathrm{ml}$ and diluted into culture medium at a final concentration of $170 \mathrm{ng} / \mathrm{ml}$.

Electrical recording. Dual recordings of synaptically coupled neurons were made in the current-clamp mode using two EPC7 patch-clamp amplifiers (List Electronics). Stimuli were applied by two S-100 stimulators (Medical Systems Corp.). Experiments were performed on line with the aid of a Data Translation $2821 \mathrm{~A} / \mathrm{D}$ converter and SPIKE (software written by Hilal Associates). Data were filtered at $2 \mathrm{kHz}$ and acquired at $6 \mathrm{kHz}$. A List L/M-3P-A vertical two-stage puller was used to fabricate electrodes from thin-walled, borosilicate glass (World Precision Instruments, TW150F-4) with resistances of 5-10 M 2 for the DRG cells and $10-15 \mathrm{M} \Omega$ for the spinal cord neurons. Because the EPC7 amplifiers have no bridge balance circuitry, the records shown include a slight error due to the electrode resistances. For the spinal neurons, which had input resistances in the $0.5-8 \mathrm{G} \Omega$ range, this error was usually too small to see. For the lower-resistance DRG neurons, an instantaneous change in recorded potential accompanying the current stimulus is often visible and reflects the voltage drop across the recording electrode.

\section{Results}

Characteristics of the neurons in coculture

As described first by Dichter and Fischbach (1977), DRG neurons can be distinguished from spinal cord neurons both morphologically and electrophysiologically. In our experiments, DRG and spinal corđ neurons were initially identified by their different morphologies. DRG neurons had large $(\sim 20-40 \mu \mathrm{m}$ diameter), ellipsoid, phase-bright cell bodies with one or two processes; spinal cord neurons, by contrast, were small $(\sim 5-15 \mu \mathrm{m}$ diameter) irregularly shaped, phase-dark cells with several highly branched processes (Fig. 1).

The two cell types were further distinguished in our experiments by their electrophysiological properties. DRG neurons were devoid of spontaneous synaptic potentials and typically had resting potentials between -50 and $-60 \mathrm{mV}$. Somatic action potentials in DRG neurons rarely occurred spontaneously but could be routinely evoked by injecting depolarizing current. The action potentials generally exhibited a broad calcium-dependent plateau on the falling phase (varying from 3 to $20 \mathrm{msec}$ in different cells). A small percentage of neurons morphologically identified as DRG neurons had no detectable calciumdependent plateau. We eliminated these from consideration in our studies of synaptic pairs in order to (1) avoid the possibility of mistakenly studying synapses between pairs of spinal neurons and (2) use the DRG somatic action potential duration as a monitor of the efficacy of applied transmitters. DRG action potentials exhibited a prominent but highly variable depolarizing afterpotential (Crain, 1971; Dichter and Fischbach, 1977; see Fig. 4). This depolarization is thought to be mediated, at least in part, by a calcium-dependent chloride current (Mayer, 1985).

In contrast, most spinal cord neurons $(\sim 80 \%)$ received frequent, spontaneous synaptic input that caused their membrane potentials to fluctuate greatly. As the input resistances of the spinal neurons were large (ranging from 0.5 to $8 \mathrm{G} \Omega$ ), the synaptic potentials were long lasting (see below) and often large enough to evoke spiking (e.g., Fig. 4B). Spinal neuron action potential duration was uniformly brief ( $\sim 2 \mathrm{msec}$ on average) and lacked the calcium-dependent plateau and depolarizing afterpotential that characterize DRG neuron spikes.

Spatial control of voltage proved problematic in spinal cord neurons. For this reason, studies were performed using current clamp techniques only. Because of the spinal neurons' high input resistances, we have assumed that synaptic potentials (even from synapses removed from the cell body) are faithfully recorded; the rising phase of the synaptic potentials, under such conditions, provides a sensitive indicator of even small changes in postsynaptic conductance. In order to monitor excitatory synaptic potentials resulting from DRG neuron stimulation, spinal neurons were held at a membrane potential near $-60 \mathrm{mV}$ using hyperpolarizing current injection.

\section{Synaptic coupling between $D R G$ and spinal cord neurons}

Stimulation of action potentials in DRG neurons evoked fast excitatory synaptic potentials in the spinal cord neurons (Fig. 2). The proportion of recorded DRG-spinal cell pairs that werc synaptically coupled varied greatly from plating to plating and ranged from 0 to $60 \%$ of pairs tested in any one experiment. Of a total of 400 pairs examined in our experiments, 105 were synaptically coupled. The latency between presynaptic stimulation and postsynaptic response was constant for a given synaptic pair and varied between 0.5 and $17.8 \mathrm{msec}(n=14)$. EPSPs were relatively long lasting, due to the large time constant of the spinal cord cell membranes. In 12 cells studied in which the monosynaptic response was unobscured by polysynaptic input, times to half-decay ranged from 19 to $120 \mathrm{msec}$ and were positively correlated with input resistance. Transmitter release was calcium dependent; superfusion of the preparation with saline solutions containing $1 \mathrm{~mm}$ cobalt to block voltage-dependent calcium currents eliminated synaptic coupling (K. Dunlap, personal communication). A small percentage of recorded pairs showed EPSPs that frequently failed or that ran down substantially during the course of the experiment. This was particularly common at the earliest culture ages studied (5-6 d in vitro). In order to minimize confounding effects of synaptic failure or fatigue, recordings were accepted for analysis only if an EPSP of near-constant amplitude could be reliably and repeatedly evoked. In addition, DRG neurons were routinely stimulated at low frequency $(0.1 \mathrm{~Hz})$ to avoid rundown. Data on inhibitory transmitter effects were accepted for analysis only when drug washout and reversal were achieved.

\section{Synaptic transmission between DRG and spinal neurons is glutamatergic}

Receptor antagonists were bath applied to determine whether synaptic transmission between DRG and spinal cord neurons in these cultures was mediated by glutamate, as is likely in vivo (Jessell et al., 1986; Yoshimura and Jessell, 1990). Kynurenate, a relatively nonselective EAA receptor blocker (Perkins and Stone, 1982), rapidly and reversibly eliminated the EPSPs at concentrations of $0.4-0.9 \mathrm{~mm}(n=4$; data not shown). To examine which glutamate receptor subtypes are involved in the postsynaptic response, we used specific antagonists to block the NMDA and non-NMDA types of glutamate receptor (Mayer and Westbrook, 1987; Honore et al., 1988). The specific nonNMDA receptor antagonist 6-cyano-7-nitroquinoxaline-2,3dione (CNQX; $2.5 \mu \mathrm{M}$ ) rapidly and reversibly blocked evoked postsynaptic responses in five of five pairs tested, without changing resting conductances or action potentials in the presynaptic DRG or postsynaptic spinal cord neurons (Fig. 2). Spontaneous synaptic activity was also eliminated by CNQX. In contrast, the NMDA receptor antagonist 5-aminophosphonovalerate (APV; $100 \mu \mathrm{M}$ ) did not alter synaptic transmission in four of four pairs tested (data not shown). No action of APV on spontancous synaptic activity was observed. 

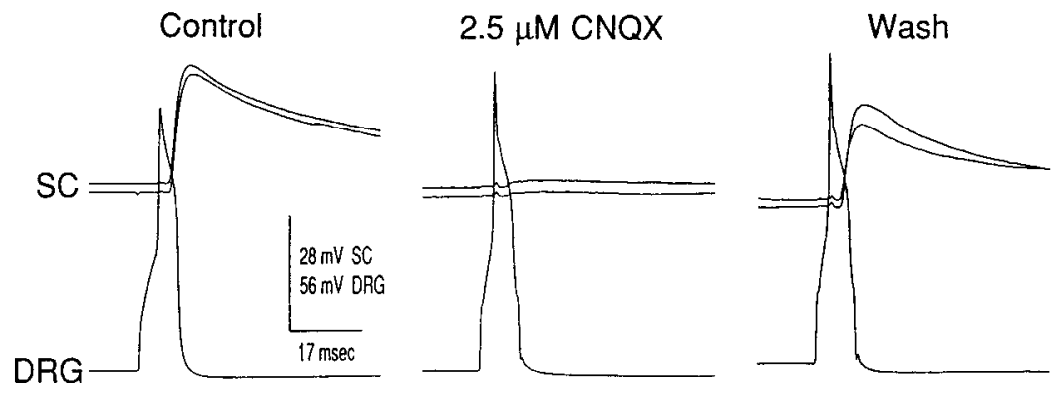

Figure 2. Synaptic transmission is blocked by CNQX. DRG neuron action potentials in response to depolarizing current injection (lower traces) evoke synaptic responses in the spinal neuron (upper traces). Two consecutive postsynaptic responscs arc shown superimposed to illustrate the degree of response variability. Center, responses of DRG and spinal neurons during bath application of $2.5 \mu \mathrm{M}$ CNQX. Right, responses after washout of CNQX.

\section{$N$-type calcium channels are essential for synaptic transmission}

High-voltage-activated calcium currents recorded in the somata of embryonic chick DRG neurons in vitro are composed predominantly of N- and L-type currents (Nowycky et al., 1985; Kasai et al., 1987). In this preparation these currents can be readily distinguished (Aosaki and Kasai, 1989; Cox and Dunlap, 1992) by $\omega$-conotoxin GVIA ( $\omega$-CTX) block (N-type) and dihydropyridine sensitivity (L-type).

In the cocultures, bath application of $1 \mu \mathrm{M} \omega$-CTX produced an irreversible blockade of evoked synaptic transmission in five of five pairs tested. This was accompanied by an elimination of the calcium-dependent action potential plateau in the DRG neuron (Fig. 3). $\omega$-CTX did not alter the input resistance or membrane potential of the postsynaptic spinal cord neurons.

To test whether $\omega$-CTX interfered with postsynaptic glutamate receptors, we compared the effects of puffer applications of L-glutamate on spinal neurons in the presence and absence of $1 \mu \mathrm{M} \omega$-CTX. Focal applications of L-glutamate $(100 \mu \mathrm{M}$ to $1 \mathrm{~mm}$ ) depolarized the neurons. Glutamate-induced depolarizations were blocked by CNQX (10 $\mu \mathrm{M}$ in the bath and puffer pipette; $n=2)$. By contrast, inclusion of $\omega$-CTX $(1 \mu \mathrm{M})$ in both the bath and puffer did not alter glutamate-induced depolarizations $(n=5$; Fig. $5 A, B)$.

\section{Synaptic transmission can be modulated by $G A B A_{B}$ receptor agonists}

$\mathrm{N}$-type calcium channels present in the somatic membranes of DRG neurons are targets for inhibitory modulation by transmitters such as GABA and norepinephrine (Miller, 1990). This transmitter-induced modulation is reversible, has been pharmacologically characterized (Canfield and Dunlap, 1984), and requires the activation of PTX-sensitive GTP-binding proteins (Holz et al., 1986). In order to test whether N-channels in DRG nerve terminals (and, as a result, synaptic transmission) might be similarly modulated, we further characterized transmitter effects on synaptic activity.

Transmission between DRG and spinal neurons was effectively suppressed by bath application of $10-100 \mu \mathrm{M}$ baclofen, a specific $\mathrm{GABA}_{\mathrm{B}}$ receptor agonist, in most of the pairs tested (13 of 14 with $10 \mu \mathrm{M}$ and 6 of 6 with $100 \mu \mathrm{M}$ ). Evoked EPSPs were abolished by $100 \mu \mathrm{M}$ baclofen; $10 \mu \mathrm{M}$ baclofen reduced EPSP amplitude by $50-100 \%$. In all cases, the effects of baclofen were readily reversed by washing the bath for 1-3 min with control saline solution. Baclofen-mediated inhibition (Fig. $4 A$ ) occurred in the absence of any changes in spinal neuron input resistance or membrane potential. The time course of baclofen's effect on synaptic potential size was precisely correlated with the time course of baclofen's effect on the DRG somatic calcium-depen-

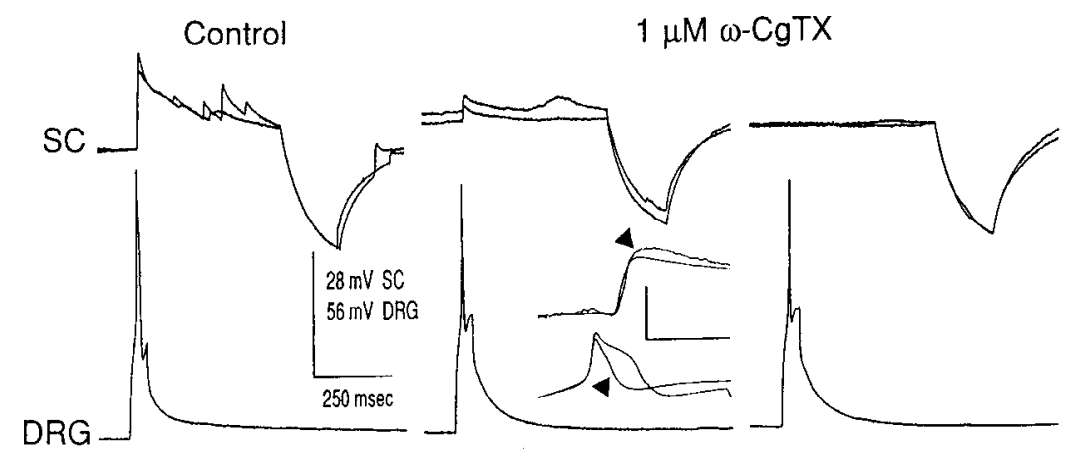

Figure 3. Synaptic transmission is $\omega$-CTX sensitive. DRG neuron action potentials in response to depolarizing current injection (lower traces) evoke synaptic responses in the spinal cord cell (upper traces). Two consecutive postsynaptic responses are shown superimposed to illustrate the degree of response variability; $200 \mathrm{msec}$ hyperpolarizing current pulses were applied to the spinal cord neuron near the end of the trace to monitor input resistance. Data shown are recorded from one DRG-spinal neuron pair before and during bath application of $1 \mu \mathrm{M} \omega$-conotoxin GVIA ( $\omega$ $C T X$ ). $\omega$-CTX reduced the width of the DRG action potential (inset) and blocked synaptic transmission (upper traces), without affecting the spinal neuron's input resistance. In early stages of the $\omega$-CTX wash (center), the EPSP amplitude and DRG action potential duration were reduced with no change in EPSP rise time. More prolonged application of $\omega$-CTX (right) completely abolished the EPSP without altering spinal neuron input resistance. The inset shows the partially reduced EPSP (arrowhead) scaled up and superimposed with a control EPSP to illustrate the coincidence in latencies and rise times for the two synaptic responses. Two superimposed DRG action potentials illustratc the action of $\omega$-CTX (arrowhead) on action potential duration. Calibration (inset): $20 \mathrm{msec} ; 20 \mathrm{mV}$ for spinal neuron, $70 \mathrm{mV}$ for DRG neuron. 
A Untreated

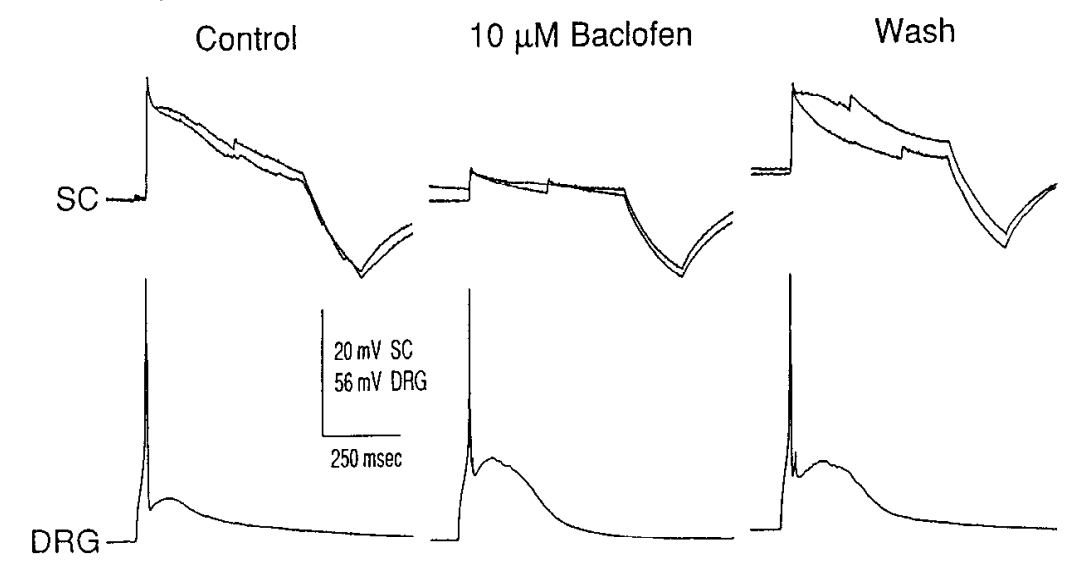

Figure 4. Baclofen reversibly inhibits synaptic transmission by a PTX-sensitive mechanism. $A$, DRG neuron action potentials in response to depolarizing current injection (lower panels) evoke synaptic responses in the spinal neuron (upper panels). Two traces from the spinal neuron recording are superimposed to illustrate the variability among responses. Near the end of the traces small (6 pA, $200 \mathrm{msec}$ ) hyperpolarizing current pulses were applied to the spinal neuron to monitor its input resistance. In $10 \mu \mathrm{M}$ baclofen (center), the EPSPs were greatly reduced, with no apparent change in spinal neuron input resistance. The effects of baclofen were readily reversed on washing for $2 \min$ (right), $B$, Cocultures were incubated in $170 \mathrm{ng} / \mathrm{ml}$ PTX for $24 \mathrm{hr}$ at $37^{\circ} \mathrm{C}$ and then tested for sensitivity to baclofen. Multiple firing was rare for DRG cells but was not the result of PTX treatment; single spinal neuron responses are shown for clarity. Responses during (center) and after washout (right) of $10 \mu \mathrm{M}$ baclofen are shown. Baclofen did not inhibit the EPSP in any of the PTX-pretreated cell pairs ( $n$ $=4$ )

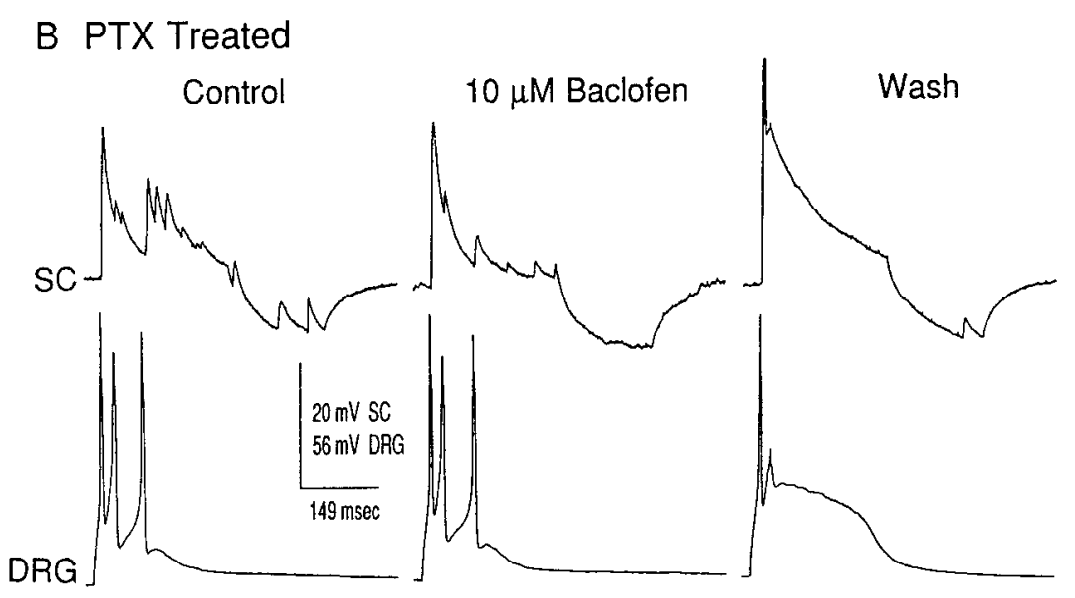

dent action potential plateau (Fig. 6). However, the magnitudes of these effects differed; the DRG somatic action potential was typically only partially reduced by baclofen, while the synaptic potential was largely or completely abolished.

In order to describe further the $\mathrm{GABA}_{\mathrm{B}}$ receptor that mediates baclofen's effects on synaptic transmission, we applied the potent and specific antagonist CGP 35348 (Olpe et al., 1990). The inhibitory action of $10 \mu \mathrm{M}$ baclofen on synaptic transmission was blocked in five of five pairs tested in the presence of 440 $\mu \mathrm{M}$ CGP 35348 (Fig. 7). The action of the antagonist was reversible upon washing; that is, a second application of baclofen (following washout of CGP 35348) again produced suppression of synaptic transmission (data not shown).

To test whether baclofen interfered with postsynaptic glutamate receptors, we compared the effects of puffer applications of L-glutamate ( $100 \mu \mathrm{M}$ to $1 \mathrm{mM}$ ) on spinal neurons in the presence and absence of baclofen. Baclofen $(100 \mu \mathrm{M}$, in the bath and puffer pipette) did not alter glutamate-induced depolarizations $(n=5$; Fig. $5 C, D)$.

In order to compare further the nerve terminal receptors that regulate release with those that regulate somatic calcium channels, we studied synaptic transmission in PTX-treated cells. Cocultures were incubated for 17-24 hr in $170 \mathrm{ng} / \mathrm{ml}$ PTX at $37^{\circ} \mathrm{C}$. Electrophysiological properties and synaptic responses in PTX-treated cells were indistinguishable from those in untreat- ed controls. In contrast to untreated controls, however, synaptic transmission in PTX-treated cells was not modulated by $10 \mu \mathrm{M}$ baclofen in any of the four pairs studied (Fig. $4 B$ ).

In addition to GABA, other transmitters such as norepinephrine also modulate DRG somatic calcium currents (Rane and Dunlap, 1990). In order to determine whether norepinephrine also modulates synaptic transmission, we tested its action on five DRG-spinal pairs. In one pair, norepinephrine $(50 \mu \mathrm{M})$ reversibly eliminated synaptic transmission and produced a clear reduction in the somatic DRG action potential duration. For the remaining four pairs, however, there was no modulation of either synaptic transmission or the DRG somatic action potential.

\section{Discussion}

In order to study neurotransmission at the primary afferent synapse, we have made tight seal, whole-cell recordings from synaptically connected DRG-spinal neuron pairs grown in dissociated cell culture. Our data demonstrate that (1) synaptic transmission between embryonic DRG neurons and spinal neurons in vitro is primarily mediated by non-NMDA glutamate receptors; (2) $\omega$-CTX-sensitive, $\mathrm{N}$-type calcium channels are necessary to trigger glutamate release from DRG axon terminals; and (3) baclofen inhibits synaptic transmission presynaptically by activating $\mathrm{GABA}_{\mathrm{B}}$ receptors coupled to PTX-sensitive GTP- 
A

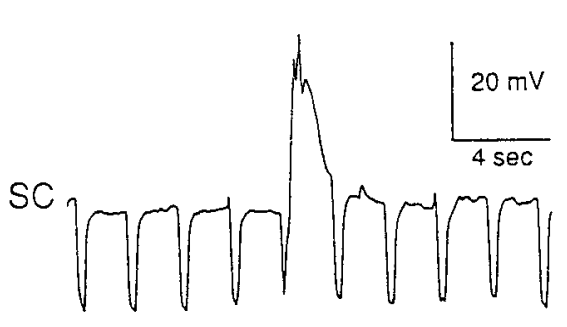

$\uparrow$

Glu
B $\quad 1 \mu \mathrm{M} \omega-\mathrm{CgTX}$

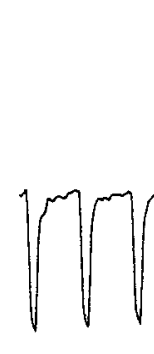

。

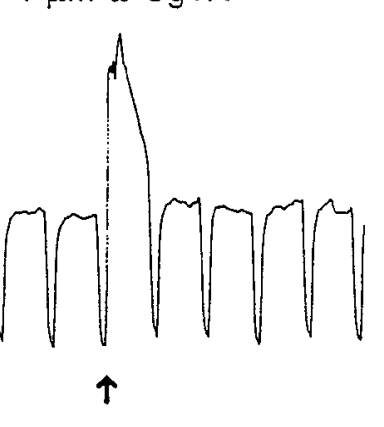

$\mathrm{Glu}+\omega-\mathrm{Cg} T \mathrm{X}$
C Control

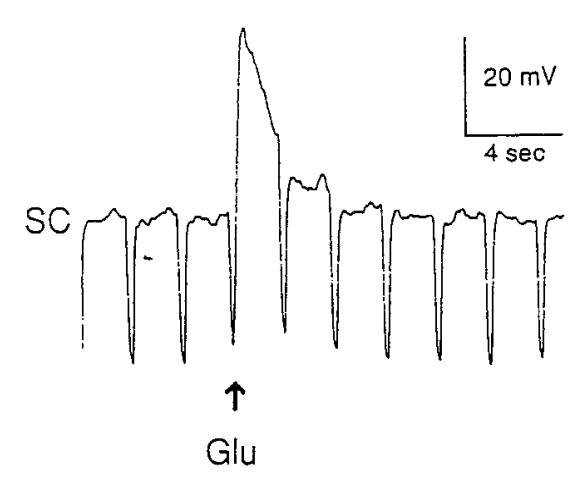

D Baclofen

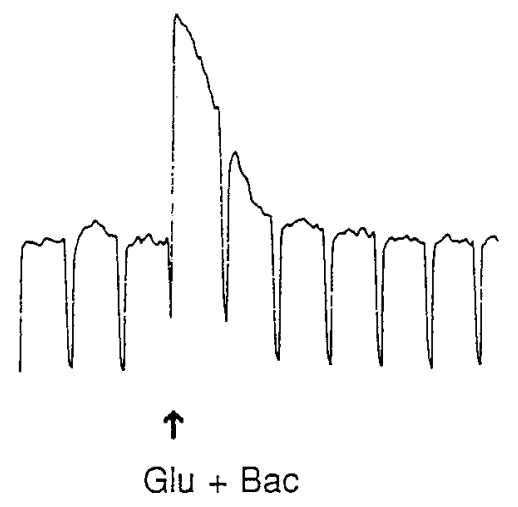

Figure 5. Neither $\omega$-CTX nor baclofen alters glutamate-induced depolarization of spinal neurons: current-clamp recordings from spinal neurons in control external solution $(A, C)$. A hyperpolarizing current pulse $(10 \mathrm{pA}, 0.5 \mathrm{~Hz})$ was delivered in order to monitor neuronal input resistance. Focally applied glutamate $(100 \mu \mathrm{M}$, arrow) evoked depolarization. Inclusion of $1 \mu \mathrm{M} \omega$-CTX $(B)$ or $100 \mu \mathrm{M}$ baclofen $(D)$ in both bath and puffer solutions did not alter glutamate-induced depolarizations. binding proteins. These data support the hypothesis that $\mathrm{GABA}_{B}$ receptor-induced presynaptic inhibition at the primary afferent synapse is mediated specifically via modulation of presynaptic N-type calcium currents.

\section{Sensory neurotransmission in the spinal cord}

Biochemical and immunocytochemical studies indicate that DRG neurons contain and release a variety of putative transmitters, including EAAs and peptides. Postsynaptic spinal cord cells are responsive to many of these agents (Brown, 1982). Despite this heterogeneity, L-glutamate is the most likely candidate for mediating fast synaptic transmission at the DRGspinal neuron synapsc (Jahr and Jesscll, 1985; Jessell ct al., 1986). Pharmacological studies in spinal cord slices have indicated that fast excitatory transmission is mediated primarily via non-NMDA type receptors, as indicated by sensitivity to CNQX and resistance to APV (Yoshimura and Jessell, 1990). The present findings in dissociated cell culture provide additional evidence that non-NMDA type glutamatergic receptors mediate fast, excitatory transmission between DRG and spinal cord neurons.

Sensory neurotransmission in the intact spinal cord is undoubtedly more complex than that seen in our culture system. By contrast to some previous reports using more intact spinal cord preparations (Dale and Grillner, 1986; Sillar and Roberts, 1988; Gerber and Randic, 1989; Pinco and Lev-Tov, 1991), synaptic potentials in the present experiments were insensitive to the NMDA receptor blocker APV. Furthermore, previous studies have shown that substance $P$, which is released from a subpopulation of DRG neurons, elicits a slow EPSP in spinal cord neurons (Urban and Randic, 1984; DeKoninck and Henry, 1991; Yoshimura et al, 1992). The present experiments did not reveal a peptide-mediated EPSP; EPSPs were consistently and completely blocked by CNQX, and a prolonged EPSP was never

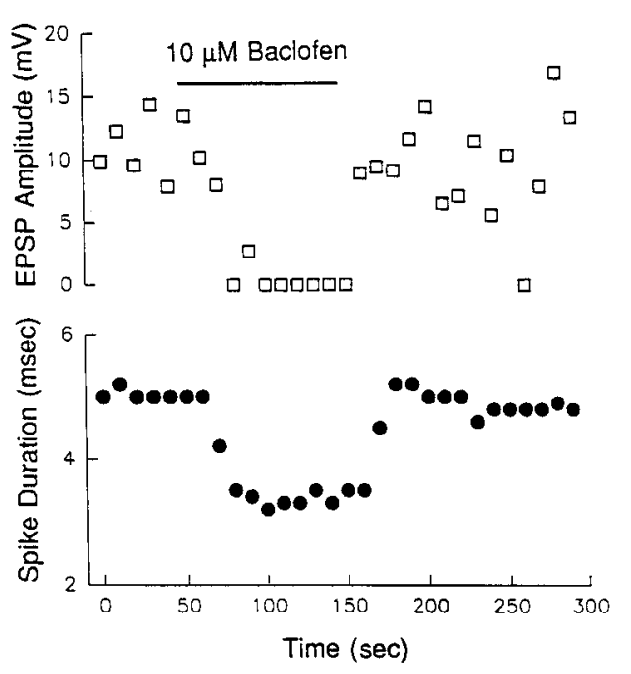

Figure 6. Time courses for baclofen-induced modulation of the calcium-dependent action potential and glutamatergic synaptic transmission. Spinal cord cell EPSP amplitude (squares) and DRG neuron action potential duration (circles) are plotted as a function of time. Application of $10 \mu \mathrm{M}$ baclofen (horizontal bar) decreased both the EPSP amplitude and action potential duration with time courses that are virtually identical. 
Figure 7. CGP 35348 , a $\mathrm{GABA}_{\mathrm{B}}$ antagonist, reversibly blocks the effects of baclofen. The lower traces (DRG) show the DRG action potentials in response to depolarizing current injections. The upper traces $(S C)$ show three consecutive spinal neuron responses evoked by DRG action potentials. Bath application of $10 \mu \mathrm{M}$ baclofen abolished synaptic transmission and reduced DRG action potential duration (inset, arrowhead). Washout of baclofen (Wash) reversed the inhibition. Application of 440 $\mu$ м CGP 35348 (rightmost panel) blocked baclofen's actions on synaptic transmission and on action potential duration (inset). Calibration (insets): 40 $\mathrm{mV}, 7 \mathrm{msec}$.

observed, even after high-frequency presynaptic stimulation. Our finding that baclofen had no postsynaptic effect on spinal cord neurons is consistent with some, but not all previous reports (Lev-Tov et al., 1988; Peng and Frank, 1989; but see also Allerton et al., 1989; Kangrga et al., 1991). Differences between the present findings and these previous reports may be due to our use of a dissociated cell preparation, or may reflect the use of embryonic tissue.

\section{Calcium channel subtypes in the control of exocytosis}

$\omega$-CTX consistently and completely abolished evoked excitatory synaptic responses recorded from spinal cord neurons. Several lines of evidence support the hypothesis that this occurred via the toxin's action on presynaptic calcium channels. It has been shown that $\omega$-CTX is highly specific for N-type calcium channels in chick sensory neurons (Cox and Dunlap, 1992). In the present experiments, the calcium-dependent plateau of the DRG action potential was blocked by $\omega$-CTX in conjunction with the blockade of synaptic transmission. Furthermore, $\omega$-CTX did not alter postsynaptic input resistance, resting membrane potential, or depolarizing responses to L-glutamate. We conclude from these observations that $\boldsymbol{\omega}$-CTX-sensitive calcium channels play an essential role in triggering glutamate release from chick DRG axon terminals. This is consistent with the results of $\mathrm{Yu}$ et al. (1992), who found that excitatory transmission between rat sensory neurons and spinal neurons was substantially reduced by $\omega$-CIX (Yu et al., 1992).

Cox and Dunlap (1992) demonstrated that $\omega$-CTX-sensitive $\mathrm{N}$-type calcium channels carry grcater than $85 \%$ of the high voltage-activated calcium current recorded from embryonic chick DRG somata. Our present results imply that calcium channel types are the same at the soma and axon terminal of DRG neurons as previously suggested by Lipscombe et al. (1988). This reinforces the hypothesis that studies of cell bodies are likely to yield insight into mechanisms at less accessible axon terminals.

$\mathrm{N}$ channels are known to trigger exocytosis from preparations in both the CNS and PNS of vertebrates (Hirning et al., 1988; Miller, 1990). The diversity of findings in different neural systems, however, underscores the necessity of continued exploration of this area. In rat DRG-spinal neuron cocultures, excitatory transmission between DRG and spinal cord neurons is substantially reduced by $\omega$-CTX; by contrast, excitatory transmission between spinal neurons was not altered by $\omega$-CTX (Yu et al., 1982). Pfrieger et al. (1992) have demonstrated that excitatory glutamatergic transmission between rat thalamic neu- rons is partially, but not primarily, mediated by $\omega$-CTX-sensitive calcium channels. Recent work with peptide and polyamine toxins from funnel web spider venom have identified a new class of calcium channel, termed P-type, that is a candidate for triggering exocytosis from nerve terminals in the mammalian CNS (Llinas et al., 1989; Mintz et al., 1992). In addition, L-typc calcium channels appear to play a minimal role as triggers of transmitter release from neurons, but dominate the control of hormone secretion from endocrine cells (Bean, 1989; Miller, 1990; Plasman et al., 1990). Thus, a single calcium channel subtype has not evolved for the exclusive control of exocytosis. Whether variation in the functional properties of the calcium channel subtypes has important implications for the control of secretion remains an open and interesting question.

\section{Mechanisms of presynaptic inhibition}

The $\mathrm{GABA}_{\mathrm{B}}$ receptor agonist baclofen reversibly inhibited synaptic transmission between DRG and spinal neurons. This inhibition was presynaptic as shown by the observations that (1) baclofen did not affect postsynaptic (spinal neuron) resting membrane potential, input resistance, or responses to focally applied glutamate, and (2) baclofen reduced both the EPSP and the calcium-dependent portion of the DRG somatic action potential with a similar time course.

These results are consistent with the hypothesis that $\mathrm{GABA}_{\mathrm{B}}$ receptor-mediated presynaptic inhibition at the primary afferent synapse works via modulation of voltage-dependent calcium channels (Dunlap, 1981; Dolphin and Scott, 1987; Lev-Tov et al., 1988). Our results support the finding by Alford and Grillner (1991) that a PTX-sensitive G-protein mediates the presynaptic $\mathrm{GABA}_{\mathrm{B}}$ response. In addition, our data suggest that presynaptic inhibition is mediated specifically via a reduction in N-type calcium current at the axon terminal.

Interestingly, $10 \mu \mathrm{M}$ baclofen largely or completely abolished the synaptic response while only partially reducing the calciumdependent plateau of the DRG somatic action potential. Baclofen may reduce the action potential duration at the nerve terminal in a similar, partial manner. Thus, the complete abolishment of the EPSP may reflect not a complete reduction of action potential duration at the nerve terminal, but rather the very steep calcium dependence of neurosecretion (Dodge and Rahamimoff, 1967). Alternatively, the difference in action of baclofen on the soma and on the synaptic response may be due to the fact that the soma is undergoing dialysis during recording while the nerve terminal is not; dialysis may result in the loss of an important mediator of the somatic $\mathrm{GABA}_{\mathrm{B}}$ receptor-me- 
diated response. In support, effects of $\omega$-CTX were equally complete on both the DRG somatic action potential and the synaptic response. $\omega$-CTX, acting through channel block, should not be susceptible to dialysis.

Some caution must be employed in the interpretation of these results, because modulation of calcium channel function is only one of the reported actions of baclofen. $\mathrm{GABA}_{\mathrm{B}}$ receptors on neurons in the spinal cord (Allerton et al., 1989; Wang and Dun, 1990; Kangrga et al., 1991) and brain (Newberry and Nicoll, 1984; Gahwiler and Brown, 1985; Howe et al., 1987; Connors et al., 1988) are coupled to the activation of a potassium conductance. Interestingly, GABAergic inputs onto hippocampal CAl pyramidal neurons are presynaptically inhibited via this potassium conductance (Thompson and Gahwiler, 1992). Furthermore, $\mathrm{GABA}_{\mathrm{B}}$ receptors have been reported to upmodulate A-type potassium current in hippocampal neurons (Saint et al., 1990). Previous voltage-clamp studies of DRG somatic currents (Dunlap and Fischbach, 1981; Robertson and Taylor, 1986) have shown that baclofen reduces calcium currents without altering resting or voltage-dependent potassium currents. In agrccment, our present results revealed a baclofen-induced reduction in the DRG calcium-dependent action potential plateau, but no effects on input resistance or resting membrane potential. Nonetheless, the possibility remains that baclofen altered potassium conductance in DRG axon terminals without our detecting it.

An additional note of caution is suggested by experiments demonstrating that presynaptic inhibition of secretion in some preparations results from an action of transmitter at a stage subsequent to calcium entry. For example, $\mathrm{ACh}$ release from motor nerve endings is inhibited by adenosine under conditions in which nerve terminal calcium channels are blocked (Silinsky, 1984). More recently, Scholz and Miller (1992) have shown that adenosine inhibits spontaneous transmitter release by cultured hippocampal neurons in a PTX-sensitive manner, even in the absence of functional calcium channels. This finding has been extended by Scanziani et al. (1992), who studied presynaptic inhibition of miniature EPSPs recorded from CA3 neurons in hippocampal slice cultures. In these studies, miniature EPSPs did not require presynaptic calcium influx through cadmiumsensitive channels. Nonetheless, baclofen strongly inhibited release via a presynaptic action. Unfortunately, an unambiguous study of baclofen's effects on miniature EPSPs was not feasible in our culture system. Because spinal neurons were excited by other spinal neurons as well as DRG neurons, miniature EPSPs would consist of both spinal-spinal and DRG-spinal synaptic potentials. These two types of synaptic potential can only be distinguished from one another when they are evoked by stimulating a specific presynaptic neuron.

It is clear from all of these studies that presynaptic inhibition is likely to involve many distinct mechanisms. Determining the underlying biological rationale for the existence of these separate inhibitory pathways remains a formidable challenge for future studies. In any case, the evolution of multiple mechanisms for the control of transmitter release serves to underscore the significance of presynaptic regulation in the control of synaptic transmission in the nervous system.

\section{References}

Alford S, Grillner S (1991) The involvement of $\mathrm{GABA}_{\mathrm{B}}$ receptors and coupled $G$-proteins in spinal GABAergic presynaptic inhibition. $J$ Neurosci 11:3718-3726.

Allerton CA, Boden PR, Hill RG (1989) Actions of the GABA $A_{B}$ ag- onist, (-)-baclofen, on neurones in deep dorsal horn of the rat spinal cord in vitro. Br J Pharmacol 96:29-38.

Aosaki N, Kasai H (1989) Characterization of two kinds of highvoltage-activated $\mathrm{Ca}$-channel currents in chick sensory neurons. Differential sensitivity to dihydropyridines and $\omega$-conotoxin GVIA. Pfluegers Arch 414:150-156.

Barber RP, Vaughn JE, Saito K, McLaughlin BT, Roberts E (1978) Gabaergic terminals are presynaptic to primary afferent terminals in the substantia gelatinosa of the rat spinal cord. Brain Res 141:35-55.

Barker JL, Nicoll RA (1973) The pharmacology and ionic dependency of amino acid responses in the frog spinal cord. J Physiol (Lond) 228: $259-277$.

Bcan BP (1989) Classes of calcium channels in vertebrate cells. Annu Rev Physiol 51:367-385.

Brown AG (1982) The dorsal horn of the spinal cord. Q J Exp Physiol 67:193-212.

Canfield DR, Dunlap K (1984) Pharmacological characterization of amine receptors on embryonic chick sensory neurones. $\mathrm{Br} \mathrm{J}$ Pharmacol 82:557-563.

Connors BW, Malenka RC, Silva LR (1988) Two inhibitory postsynaptic potentials, and $\mathrm{GABA}_{\mathrm{A}}$ and $\mathrm{GABA}_{\mathrm{B}}$ receptor-mediated responses in neocortex of rat and cat. J Physiol (Lond) 406:443-468.

Cox DH, Dunlap K (1992) Pharmacological discrimination of N-type from L-type calcium current and its selective modulation by transmitters. J Neurosci 12:906-914.

Crain S (1971) Intracellular recordings suggesting synaptic functions in chick embryo spinal cord sensory ganglion cells isolated in vitro. Brain Res 26:188-191.

Curtis DR, Duggan AW, Felix D, Johnston GAR (1971) Bicuculline, an antagonist of GABA and synaptic inhibition in the spinal cord of the cat. Brain Res 32:69-96.

Dale N, Grillner S (1986) Dual-component synaptic potentials in the lamprey mediated by excitatory amino acid receptors. J Neurosci 6:2653-2661.

Davies J (1981) Selective depression of synaptic excitation in cat spinal neurones by baclofen: an iontophoretic study. $\mathrm{Br} \mathrm{J}$ Pharmacol 72: 373-384.

DeBiasi S, Rustioni A (1988) Glutamate and substance P coexist in primary afferent terminals in the superficial laminae of spinal cord. Proc Natl Acad Sci 85:7820-7824.

DeKoninck Y, I Ienry JL (1991) Substance P-mediated slow excitatory postsynaptic potential elicited in dorsal horn neurons in vivo by noxious stimulation. Proc Natl Acad Sci USA 88:11344-11348.

Dichter MA, Fischbach GD (1977) The action potential of chick dorsal root ganglion neurones maintained in cell culture. J Physiol (Lond) 267:281-298.

Dickenson AH, Brewer CM, Hayes NA (1985) Effects of topical baclofen on $\mathrm{C}$ fibre-evoked neuronal activity in the rat dorsal horn. Neuroscience 14:557-562.

Dodge FA, Rahamimoff R (1967) Cooperative action of calcium ions in transmitter release at the neuromuscular junction. $J$ Physiol (Lond) 193:419-432.

Dolphin AC, Scott RH (1987) Calcium channel currents and their inhibition by $(-)$-baclofen in rat sensory neurones: modulation by guanosine nucleotides. J Physiol (Lond) 386:1-17.

Dunlap K (1981) Two types of $\gamma$-aminobutyric acid receptor on embryonic sensory neurones. Br J Pharmacol 74:579-585.

Dunlap K, Fischbach GD (1981) Neurotransmitters decrease the calcium conductance activated by depolarization of embryonic chick sensory neurons. J Physiol (Lond) 317:519-535.

Eccles JC (1964) The physiology of synapses. Berlin: Springer.

Eccles JC, Eccles RM, Magni F (1961) Central inhibitory action attributable to presynaptic depolarization produced by muscle afferent volleys. J Physiol (Lond) 159:147-166.

Eccles JC, Schmidt RF, Willis WD (1963) Pharmacological studies on presynaptic inhibition. J Physiol (Lond) 168:500-530.

Fabiato A, Fabiato F (1979) Calculator programs for computing the composition of the solutions containing multiple metals and ligands used for expcriments in skinned muscle cells. J Physiol (Paris) 75: 463-505.

Gahwiler BH, Brown DA (1985) GABA $_{\mathrm{B}}$-receptor-activated $\mathrm{K}^{+}$current in voltage-clamped CA3 pyramidal cells in hippocampal cultures. Proc Natl Acad Sci USA 82:1558-1562.

Gerber G, Randic M (1989) Participation of excitatory amino acid receptors in the slow excitatory synaptic transmission in the rat spinal dorsal horn in vitro. Neurosci Lett 106:220-228. 
Gruner W, Silva LR, Dunlap K (1992) $\omega$-Conotoxin-sensitive calcium current mediates presynaptic inhibition at the sensory neuron-spinal cord synapse. Soc Neurosci Abstr 18:247.

Hirning LD, Fox AP, McCleskey EW, Olivera BM, Thayer SA, Miller RJ, Tsien RW (1988) Dominant role of N-type calcium channels in evoked release of norepinephrine from sympathetic neurons. Science 239:57-61

Hokfelt T, Lelde R, Johansson O, Luft R, Nilsson G, Arimua A (1976) Immunohistochemical evidence for separate populations of somatostatin-containing and substance P-containing primary afferent neurons in the rat. Neuroscience 1:131-136.

Holz GG, Rane SG, Dunlap K (1986) GTP-binding proteins mediate transmitter inhibition of voltage-dependent calcium channels. Nature 319:670-672.

Honore T, Davies SN, Drejer J, Fletcher EJ, Jacobsen P, Lodge D, Nielsen FE (1988) Quinoxalinediones: potent competitive nonNMDA glutamate receptor antagonists. Science 241:701-703.

Howe JR, Sutor B, Zieglgansberger W (1987) Baclofen reduces postsynaptic potentials of rat cortical neurones by an action other than its hyperpolarizing action. J Physiol (Lond) 384:539-569.

Jahr CE, Jessell TM (1985) Synaptic transmission between dorsal horn neurons in culture: antagonism of monosynaptic EPSPs and glutamate excitation by kynurenate. J Neurosci 5:2281-2289.

Jessell TM, Yoshioka K, Jahr CE (1986) Amino acid receptor-mediated transmission at primary afferent synapses in rat spinal cord. $\mathrm{J}$ Exp Biol 124:239-258.

Jimenez I, Rudomin P, Enriquez M (1991) Differential effects of (-)baclofen on Ia and descending monosynaptic EPSPs. Exp Brain Res 85:103-113.

Kangrga I, Randic M (1991) Outflow of endogenous aspartate and glutamate from the rat spinal dorsal horn in vitro by activation of low- and high-threshold primary afferent fibers. Modulation by m-opioids. Brain Res 553:347-352.

Kangrga I, Jiang M, Randic M (1991) Actions of (-)-baclofen on rat dorsal horn neurons. Brain Res 562:265-275.

Kasai H, Aosaki T, Fukuda J (1987) Presynaptic Ca-antagonist $\omega$-conotoxin irreversibly blocks $\mathrm{N}$-type $\mathrm{Ca}$-channels in chick sensory neurons. Neurosci Res 4:228-235.

Lev-Tov A, Meyers DER, Burke RE (1988) Activation of type B $\omega$-aminobutyric acid receptors in the intact mammalian spinal cord mimics the effects of reduced presynaptic $\mathrm{Ca}^{2+}$ influx. Proc Natl Acad Sci USA 85:5330-5334.

Lipscombe D, Madison DV, Poenie M, Reuter H, Tsien RY, Tsien RW (1988) Spatial distribution of calcium channels and cytosolic calcium transients in growth cones and cell bodies of sympathetic neurons. Proc Natl Acad Sci USA 85:2398-2402.

Llinas RR, Sugimori M, Lin JW, Cherksey B (1989) Blocking and isolation of a calcium channel from neurons in mammals and cephalopods utilizing a toxin fraction (FTX) from funnel-web spider poison. Proc Natl Acad Sci USA 86:1689-1693.

Mayer ML (1985) A calcium-activated chloride current generates the after-depolarization of rat sensory neurones in culture. J Physiol (Lond) 364:217-239.

Mayer ML, Westbrook GL (1987) The physiology of excitatory amino acids in the vertebrate central nervous system. Prog Neurobiol 28 : 197-276.

Miller R (1990) The receptor mediated regulation of calcium channels and neurotransmitter release. FASEB J 4:3291-3300.

Mintz IM, Venema VJ, Swiderek KM, Lee TD, Bean BP, Adams ME (1992) P-type calcium channels blocked by the spider toxin $\omega$-AgaIVA. Nature 355:827-829.

Newberry NR, Nicoll RA (1984) Direct hyperpolarizing action of baclofen on hippocampal pyramidal cells. Nature 308:450-452.

Nowycky MC, Fox AP, Tsien RW (1985) Three types of neuronal calcium channel with different calcium agonist sensitivity. Nature 316:440-443.

Olpe HR, Karlsson G, Pozza MF, Brugger F, Steinmann M, Van Reizen H, Fagg G, Hall RG, Froestl W, Bittiger H (1990) CGP 35348: a centrally active blocker of $\mathrm{GABA}_{\mathrm{B}}$ receptors. Eur J Pharmacol 187: $27-38$.

Paredes RG, Agmo A (1992) GABA and behavior: the role of receptor subtypes. Neurosci Biobehav Rev 16:145-170.

Peng Y-Y, Frank E (1989) Activation of $\mathrm{GABA}_{\mathrm{B}}$ receptors causes presynaptic inhibition at synapses between muscle spindle afferents and motoneurons in the spinal cord of bullfrogs. J Neurosci 9:15021515.

Perkins NM, Stone TW (1982) An iontophoretic investigation of the actions of convulsant kynurines and their interaction with the endogenous excitant quinolinic acid. Brain Res 241:184-187.

Pfrieger FW, Veselovsky NS, Gottmann K, Lux HD (1992) Pharmacological characterization of calcium currents and synaptic transmission between thalamic neurons in vitro. J Neurosci 12:4347-4357.

Pinco M, Lev-Tov A (1991) Frequency modulation of NMDA and non-NMDA receptor-mediated EPSPs in the neonatal rat spinal cord. Soc Neurosci Abstr 21:464.

Plasman PO, Hermann M, Herchuelz A, Lebrun P (1990) Sensitivity to $\mathrm{Cd}^{2+}$ but resistance to $\mathrm{Ni}^{2+}$ of $\mathrm{Ca}^{2+}$ inflow into rat pancreatic islets. Am J Physiol 258:E529-E533.

Price GW, Wilkin GP, Turnbull MJ, Bowery NG (1984) Are baclofensensitive $\mathrm{GABA}_{\mathrm{B}}$ receptors present on primary afferent terminals of the spinal cord? Nature 307:71-74.

Rane SG, Dunlap K (1990) G protein and protein kinase C mediatcd regulation of voltage-dependent calcium channels. In: $G$ proteins (Iyengar R, Birnbaumer L, eds), pp 357-381. San Diego: Academic.

Roberts PJ (1974) The release of amino acids with proposed transmitter function from the cuneate and gracile nuclei of the rat, in vivo. Brain Res 67:419-428.

Robertson B, Iaylor WR (1986) Effects of $\omega$-aminobutyric acid and (-)-baclofen on calcium and potassium currents in cat dorsal root ganglion neurones in vitro. Br J Pharmacol 89:661-672.

Saint DA, Thomas T, Gage PW (1990) $\mathrm{GABA}_{\mathrm{B}}$ agonists modulate a transient potassium current in cultured mammalian hippocampal neurons. Neurosci Lett 118:9-13.

Scanziani M, Capogna M, Gahwiler BH, Thompson SM (1992) Presynaptic inhibition of miniature excitatory synaptic currents by baclofen and adenosine in the hippocampus. Nature 9:919-927.

Scholz KP, Miller RJ (1992) Inhibition of quantal transmitter release in the absence of calcium influx by a $G$ protein-linked adenosine receptor at hippocampal synapses. Neuron 8:1139-1 150 .

Segal MM, Furshpan EJ (1990) Epileptiform activity in microcultures containing small numbers of hippocampal neurons. J Neurophysiol 64:1390-1399.

Silinsky EM (1984) On the mechanism by which adenosine receptor activation inhibits the release of acetylcholine from motor nerve endings. J Physiol (Lond) 346:243-256.

Sillar KT, Roberts A (1988) Unmyelinated cutaneous afferent neurons activate two types of excitatory amino acid receptor in the spinal cord of Xenopus laevis embryos. J Neurosci 8:1350-1360.

Thompson SM, Gahwiler BH (1992) Comparison of the actions of baclofen at pre- and postsynaptic receptors in the rat hippocampus in vitro. J Physiol (Lond) 451:329-345.

Urban L, Randic M (1984) Slow excitatory transmission in rat dorsal horn: possible mediation by peptides. Brain Res 290:336-341.

Wang MY, Dun NJ (1990) Phaclofen-insensitive presynaptic inhibitory action of $(+)$-baclofen in neonatal rat motoneurones in vitro. $\mathrm{Br}$ J Pharmacol 99:413-421.

Yoshimura M, Jessell T (1990) Amino acid-mediated EPSPs at primary afferent synapses with substantia gelatinosa neurones in the rat spinal cord. J Physiol (Lond) 430:315-335.

Yoshimura M, Shimizu T, Nishi S (1992) Slow EPSPs and responses to substance $P$ of dorsal horn neurons in the adult rat spinal cord slices. Soc Neurosci Abstr 18:1353.

Yu C, Lin P-X, Fitzgerald S, Nelson P (1992) Heterogeneous calcium currents and transmitter release in cultured mouse spinal cord and dorsal root ganglion neurons. J Neurophysiol 67:561 $\$ 575$. 